\title{
Isolation and characterization of a pathogenic bacterium specific to Manila clam Tapes philippinarum larvae
}

\author{
J. L. Nicolas, D. Ansquer, J. C. Cochard \\ Microbiologie, Aquaculture, Centre de Brest, Ifremer, BP 70, F-29280 Plouzané, France
}

\begin{abstract}
A bacterial strain belonging to the genus Vibrio was involved in a recurrent outbreak of disease in Manila clam Tapes philippinarum larvae at a commercial hatchery. This vibrio, named VTP for convenience, was not related to the known pathogenic vibrios and possessed unusual characteristics. Only Manila clam larvae and postlarvae were affected by the disease. Oyster and scallop larvae were not affected by VTP. Survival of VTP was found to be of short duration in seawater but even a very small number of cells (1 cell per $5 \mathrm{ml}$ ) could initiate the disease. VTP did not grow on thiosulfate-citratebile-sucrose agar and was resistant to chloramphenicol. An epidemiological study utilizing bioassays revealed the presence of VTP in adult bivalves and in the pond-inlet seawater. Drying the facilities and pond used to produce phytoplankton eliminated VTP.
\end{abstract}

\section{INTRODUCTION}

The Manila clam Tapes philippinarum was introduced into western Europe about 15 yr ago because of its high growth rate and its commercial value. Larval rearing as well as growing on beds were considered relatively easy. However, 2 new diseases have recently been observed in this species. 'Brown ring' disease, due to a Vibrio sp. (Paillard \& Maes 1990), has occurred in adults since 1987, and a disease of larvae and postlarvae appeared in 1986 in a French commercial hatchery. The latter, reported here and caused by another Vibrio sp., killed almost all Manila clam larvae and between 30 and $50 \%$ of postlarvae, while oyster larvae mixed with the Manila clam larvae survived without any disease. An antibiotic (chloramphenicol) did not prevent mortality. Until 1986, no important disease had been observed in bivalve larvae at hatcheries in France; however, some investigators had already reported many cases of bacterial attacks in other countries. Brown (1973) demonstrated that several bacteria belonging to the genera Vibrio or Pseudomonas, isolated from moribund oyster larvae in Connecticut (USA), could induce disease in the larvae. DiSalvo et al. (1978) isolated Vibrio anguillarum causing larval mortality of Crassostrea gigas in California. Elston \& Leibovitz (1980) summarized the various bacterial attacks and described 3 different types of pathogenesis in oyster larvae due to vibrios from hatcheries on Long Island (USA). More recently, Garland et al. (1983) reported mortality of oyster larvae due to bacterial pathogens in Tasmania (Australia). In addition, Lodeiros et al. (1987) found that mortality of flat oyster Ostrea edulis larvae was related to a high level of Vibrio tubiashii in 2 hatcheries in Spain. Most of these workers used bioassays to test the pathogenicity of the isolates. In this study, bioassays were also conducted, permitting identification of the causal agent (referred to here as VTP).

\section{MATERIALS AND METHODS}

Bioassays were used to prove that the disease reported here was infectious, to look for the causal agent and to satisfy Koch's postulates. Different experiments utilizing bioassays also permitted determination of the lethal dose of pathogenic bacterium, the susceptibility of oyster and scallop larvae and the survival of the pathogenic bacterium. In addition, an epidemiological study was conducted using the same method because, as indicated by the results, it was very efficient for detecting the presence of VTP. Other methods, including indirect immunofluorescene with 
polyclonal antibodies against the pathogenic bacterium and assays with lysozyme, permitted us to observe survival of the pathogenic bacterium in seawater and to attempt to elucidate the mechanism of infection.

Bioassays. Broodstock Manila clams were induced to spawn by thermal shock. After addition of sperm following the method described by Gruffydd \& Beaumont (1972) the eggs were placed in filtered $(1 \mu \mathrm{m})$ seawater $\left(20^{\circ} \mathrm{C}, 3.5 \% \mathrm{~S}\right)$ in $150 \mathrm{l}$ conical tanks and allowed to develop into veliger larvae at a concentration of 15 larvae $\mathrm{ml}^{-1}$. Larval density was then reduced to 5 larvae $\mathrm{ml}^{-1}$. The larvae were reared in the same tanks and fed 50 cells $\mu^{-1}$ of Isochrisis affinis galbana (T-iso) until they were used for bioassays. The bioassays were performed with 2 to $16 \mathrm{~d}$ old veligers and $55 \mathrm{~d}$ old juveniles. Larvae were held at a density of 5 ind. $\mathrm{ml}^{-1}$ and postlarvae at 50 ind. $\mathrm{l}^{-1}$. They were fed with $\mathrm{T}$-iso, supplied daily at 50 to 100 cells $\mu^{-1}$. Seawater with 8 ppm chloramphenicol was renewed every 2 to $3 \mathrm{~d}$. The first experiment was conducted with two $150 \mathrm{l}$ conical tanks. Five liters of seawater containing diseased larvae from the commercial hatchery was poured into one of two 150 l larval rearing tanks. Mortality was observed for $1 \mathrm{wk}$. For other bioassays, larvae were maintained in glass beakers containing $2 \mathrm{l}$ of $1 \mu \mathrm{m}$ filtered seawater. Three replicate beakers were set up for each experimental treatment.

Sensitivity of Pecten maximus and Crassostrea gigas larvae to VTP was tested in a 2 I beaker with conditions similar to those for Manila clam larvae.

Epidemiological study. The source of contamination was investigated in the hatchery by taking samples from different areas (Fig. 1; see also Table 4) and

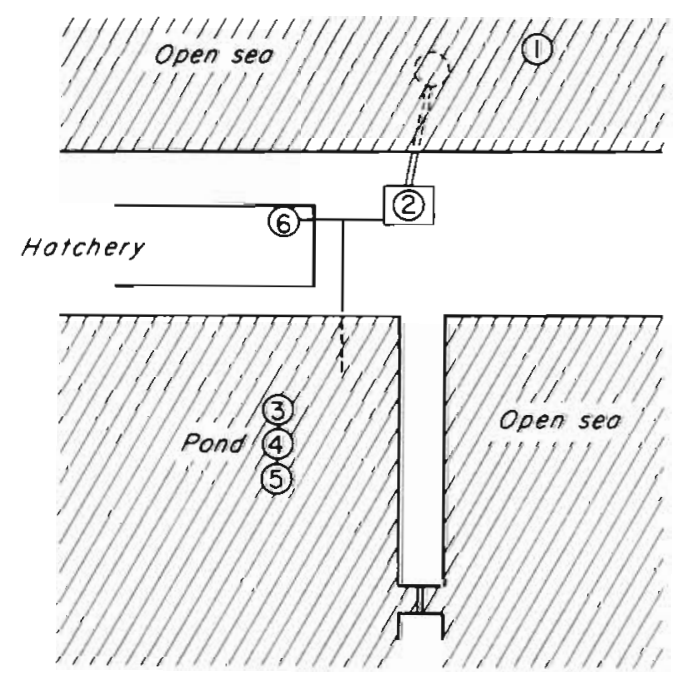

Fig. 1 Sampling areas for the epidemiological study in the hatchery and its surrounding environment (see Table 4). (1) Sand; (2) water in tank; (3) bivalves in pond; (4) sediment in pond; (5) water in pond; (6) water after the sand filter testing them in bioassays. The samples were: (1) $0.1 \mathrm{~g}$ of sand collected above the pump; (2) $300 \mathrm{ml}$ of tank seawater; (3) $0.2 \mathrm{ml}$ of digestive content removed from different adult bivalves (Mercenaria mercenaria and Tapes philippinarum) obtained from the pond; (4) $0.1 \mathrm{~g}$ of pond sediment; (5) $300 \mathrm{ml}$ of pond seawater; (6) 300 $\mathrm{ml}$ of inlet seawater after the sand filter.

Bacteriology. After filtration on a $45 \mu \mathrm{m}$ plankton net, the seawater samples were diluted and plated on 2216 E Zobell agar and thiosulfate-citrate-bile-sucrose agar (TCBS). Live larvae were rinsed with sterile seawater, counted, ground, diluted and plated on the same media. Colonies were sampled on Zobell agar and identified using commercial systems, including API $20 \mathrm{E}$ and API 20NE multiple test strips. The diluent for inoculation of API $20 \mathrm{E}$ was composed of $60 \%$ seawater and $40 \%$ distilled water to avoid false reactions as observed by Kent (1982) and MacDonell et al. (1982) with the dilnent recommended by the manufacturer $(0.85 \% \mathrm{NaCl})$. For API $20 \mathrm{NE}, 2 \% \mathrm{Nacl}$ was added to the diluent provided by the manufacturer. Additional characters were determined in microtitration plates or on agar plates (see Table 2).

Antiserum. Polyclonal antibodies were made in rabbits by successive intravenous injections of $10^{8}$ cells $\mathrm{ml}^{-1}$ of a saline-washed suspension of VTP cultured on Zobell agar for $24 \mathrm{~h}$ after isolation and characterization; injections were given over a period of $8 \mathrm{wk}$ according to the following schedule: twice with $0.25 \mathrm{ml}$ the first week, twice with $0.5 \mathrm{ml}$ the second week and $1 \mathrm{ml}$ every week for $5 \mathrm{wk}$. One week after the last inoculation, the rabbit was bled and the separated serum was freeze-dried. Specificity was tested by direct agglutination against Vibrio parahaemoliticus, $V$. anguillarum, $V$. alginolyticus and the vibrio of brown ring disease. Some controls were performed with uncontaminated seawater and larvae. No fluorescent bacteria were observed in uncontaminated seawater and larvae by the indirect immunofluorescence method described below.

Indirect immunofluorescence. In order to detect the pathogenic bacterium, $100 \mathrm{ml}$ of seawater were prefiltered at $3 \mu \mathrm{m}$ to eliminate microalgae, then filtered through a $0.2 \mu \mathrm{m}$ black Nuclepore filter (diameter: 25 $\mathrm{mm})$. The filter was incubated with a 1:300 dilution of antiserum in $0.9 \%$ PBS for 30 min. After washing with PBS, $1 \mathrm{ml}$ of a $1: 500$ dilution of fluorescein isothiocyanate-conjugated goat anti-rabbit IgG in PBS was added. The filter was washed again and examined by epifluorescence microscopy. Twenty larvae were ground in $2 \mathrm{ml}$ of sterile water and the same process as for the seawater was performed except that $3 \mu \mathrm{m}$ filtration was not carried out.

Electron microscopy. Samples of larvae were fixed in Carlson medium and decalcified by $10 \%$ formic acid 
(pH 4.5). Larval tissues were examined by transmission electron microscopy (TEM).

Susceptibility to lysozyme activity. According to Birkbeck \& McHenery (1982) lysozyme is the main enzyme in bivalves which can lyse bacteria in the digestive tract. Thus, the susceptibility of VTP and other bacteria to lysozyme activity was tested using lysozyme from scallop and oyster larvae (unfortunately Manila clam larvae were no longer available for this test). The crude extracts of lysozyme from oyster and scallop larvae were prepared as follows: larvae $\left(5 \times 10^{4}\right.$ ind.) were ground in $1 \mathrm{ml}$ of distilled water with $0.1 \mathrm{M}$ $\mathrm{NaCl}$ added, and were centrifuged at $1000 \times g$ to separate the shell debris. The supernatant was heated at $35^{\circ} \mathrm{C}(\mathrm{pH} 4.6)$ for $10 \mathrm{~min}$. The precipitate was eliminated by centrifugation $(1000 \times g)$ and the supernatant containing the lysozyme was stored at $-20^{\circ} \mathrm{C}$ or immediately used. Lysozyme of chicken egg white (CEW) at $80 \mu \mathrm{g} \mathrm{ml} \mathrm{m}^{-1}$ (Sigma) and Micrococcus lysodeikticus were used as references. The pathogenic bacterium was tested as well as other gram-negative bacteria, including Escherichia coli and Vibrio anguillarum. Lysis of bacteria by lysozyme was observed using a method similar to that of McHenery \& Birkbeck (1982). M. lysodeikticus cell walls $\left(0.1 \mathrm{mg} \mathrm{ml}^{-1}\right)$ were suspended in $3 \mathrm{ml}$ barbital acetate buffer ( $\mathrm{pH} 4.8,0.011$
M) with $0.05 \mathrm{M} \mathrm{NaCl}$. The suspensions of other bacteria were prepared at the same optical density measured at $600 \mathrm{~nm}$. Fifty microliters of bivalve lysozymes, CEW lysozyme or distilled water were added to $3 \mathrm{ml}$ suspensions and the changes in absorbance at $600 \mathrm{~nm}$ and $25^{\circ} \mathrm{C}$ were monitored at 1 min intervals for $10 \mathrm{~min}$.

\section{RESULTS}

\section{Isolation and identification of the causal agent}

In the first experiment, mortality of larvae started $2 \mathrm{~d}$ after initiation of the bioassays in the contaminated tank, whereas no mortality was observed in the control. The bacterial flora of diseased larvae contained only one dominant species which grew on Zobell agar. Five colonies were collected at random and identified. All had identical characters (Table 1) and could be classified as Vibrio sp. with a close affinity to Vibrio marinus based on the criteria given by Baumann et al. (1984) and West \& Colwell (1984). No viral structures were observed by TEM.

In order to test the pathogenicity of the bacterium, larvae were inoculated with $5 \mathrm{ml}$ of seawater from the hatchery, $5 \mathrm{ml}$ of algal culture from the hatchery, $0.5 \mathrm{ml}$

Table 1. Characters of Vibrio sp. isolated from Tapes philippinarum. Traits were determined using API systems $20 \mathrm{E}$ and $20 \mathrm{NE}$, an agar plate and a microtitration plate. I: intermediate. Traits of Vibrio marinus which differ from those of VTP are given in parentheses

Gram
Motility
Fermentative
Production of:
Indol
acetylmethylcarbinol
(Voges-Proskauer test)
Presence of:
Oxydase
Catalase
Nitrate reductase
B-Galactosidase
Gelatinase
Lysine decarboxilase
Arginine dehydrolase
Ornithine decarboxylase
Acid from:
Glucose
Mannitol
Inositol
Sorbitol
Rhamnose
Sucrose
Melibiose
Amygdaline
L-Arabinose

-
+
+
+
+


+
+
+
+
+
+
+
+
+
+
+
+
+
+
+
+

$\begin{array}{ll}\text { Sensitivity to: } & + \\ 0 / 129(400 \mu \mathrm{g}) & - \\ \text { Chloramphenico } & \text { I } \\ \text { Penicillin } & \text { I } \\ \text { Oxytetracyclin } & + \\ \text { Furane } & + \\ \text { Streptomycin } & \text { I } \\ \text { Flumequin } & \text { I } \\ \text { Oxolinate } & \\ \text { Growth at: } & -(+) \\ 4{ }^{\circ} \mathrm{C} & - \\ 42{ }^{\circ} \mathrm{C} & - \\ 0.2 \% \mathrm{NaCl} & + \\ 3 \% \mathrm{NaCl} & - \\ 6 \% \mathrm{NaCl} & - \\ 8 \% \mathrm{NaCl} & \\ \text { Growth in single source of carbon: } & - \\ \text { Arbutin } & - \\ \text { glucosamine } & +(-) \\ \text { Cellobiose } & -(+) \\ \text { Gluconate } & - \\ \text { D-Glucuronate } & - \\ \text { Sucrose } & - \\ \text { L-Arabinose } & - \\ \text { Ethanol } & -(+) \\ \text { Growth on TCBS } & \end{array}$


Table 2. Tapes philippinarum infected by Vibrio sp. Mortality $(\%$; SD in parentheses) of Manila clam larvae inoculated with different samples, and bacterial counts in larvae on Day 5. Control: nothing; SW: $5 \mathrm{ml}$ of seawater from hatchery; Al: $5 \mathrm{ml}$ of algal culture from hatchery; La: $0.5 \mathrm{ml}$ of ground diseased larvae; LaF: $0.5 \mathrm{ml}$ of $0.2 \mu \mathrm{m}$ filtrate of the ground diseased larvae; B: $10^{4} \mathrm{ml}^{-1}$ (final concentration) of bacteria isolated from larvae of the previous mortality bioassay. nd: not determined

\begin{tabular}{|c|c|c|c|c|}
\hline \multirow[t]{2}{*}{ Batches } & \multicolumn{2}{|c|}{ Days after inoculation } & \multicolumn{2}{|c|}{ No. bacteria larva ${ }^{-1}$} \\
\hline & 3 & 5 & Zobell & TCBS \\
\hline Control & $1.6(1.5)$ & $11.4 \quad(7.0)$ & nd & \\
\hline SW & $3.2(2.7)$ & $76.2(15.2)$ & $1.0 \times 10^{4}$ & 51 \\
\hline $\mathrm{Al}$ & $0.7(1.2)$ & $7.6 \quad(6.7)$ & nd & \\
\hline La & $20.5(9.6)$ & $93.2 \quad(4.7)$ & $2.4 \times 10^{3}$ & 760 \\
\hline $\mathrm{LaF}$ & $1.4(1.6)$ & $9.1 \quad(8.7)$ & nd & \\
\hline $\mathrm{B}$ & $11.7(4.2)$ & $90.2 \quad(8.5)$ & $5.3 \times 10^{3}$ & 2 \\
\hline
\end{tabular}

of ground diseased larvae or $0.5 \mathrm{ml}$ of a $0.2 \mu \mathrm{m}$ filtrate of ground diseased larvae as indicated in Table 2. An additional batch received VTP at a final concentration of $10^{4}$ cells $\mathrm{ml}^{-1}$. Algal inoculum and $0.2 \mu \mathrm{m}$ filtrate of ground larvae did not result in disease (Table 2). In contrast, VTP, ground larvae and seawater samples induced mortality. The VTP was subsequently isolated in high numbers from those batches inoculated with seawater and VTP but not from the group inoculated with ground larvae. Small numbers of vibrios from diseased larvae were observed on TCBS agar, except from the ground larvae batch (Table 2).

Mortality appeared more slowly in postlarvae (Table 3). Only $21 \%$ of postlarvae were dead $8 \mathrm{~d}$ after the inoculation.

Table 3. Tapes philippinarum infected by Vibrio sp. Sensitivity of 55 d old Manila clam postlarvae to VTP; values are mortality in percent (SD in parentheses). Control: without inoculation; Inoculate: inoculated with 100 cells ml-1 of VTP

\begin{tabular}{|lcccc|}
\hline Batches & \multicolumn{3}{c}{ Days after inoculation } \\
& 6 & 7 & 8 \\
\hline Control & $1.2(1.1)$ & $4.1(1.8)$ & $4.2(2.2)$ \\
Inoculate & $5.4(3.4)$ & $17.8(11.3)$ & $20.8(12.6)$ \\
\hline
\end{tabular}

\section{Epidemiological study}

Only the sample of bivalve digestive contents collected from the pond clearly induced disease (Table 4). Inlet seawater taken in the hatchery induced a lesser mortality.

In another experiment, VTP added at a final concentration of $4 \times 10^{5}$ cells ml $\mathrm{m}^{-1}$ into $2 \mathrm{l}$ of seawater without larvae disappeared quickly (Fig. 2). After $7 \mathrm{~d}$ it was no
Table 4. Vibrio sp. Epidemiological study to locate VTP using bioassays; values are mortality of Tapes philippinarum in percent (SD in parentheses). Numbered sampling areas correspond to those indicated on Fig. 1. Control: nothing; Sd (1): $0.1 \mathrm{~g}$ of sand collected above the pump; $\mathrm{SW}_{\mathrm{t}}(2): 300 \mathrm{ml}$ of tank seawater; Biv (3): $0.2 \mathrm{ml}$ of digestive content removed from different bivalves collected in the pond (used as reservoir for seawater and phytoplankton); $S D_{p}(4): 0.1 \mathrm{~g}$ of pond sediment; $S W_{\mathrm{p}}$ (5): $300 \mathrm{ml}$ of pond seawater; $\mathrm{SW}_{\mathrm{h}}(6): 300 \mathrm{ml}$ of inlet seawater after the sand filter

\begin{tabular}{|lrrrl}
\hline Batches & \multicolumn{4}{c}{ Days after inoculation } \\
& 4 & 6 & 8 \\
\hline Control & $9.6(4.0)$ & $5.9(2.7)$ & $<10$ \\
Sd (1) & $0.9(1.3)$ & $0.2(0.3)$ & $<10$ \\
SW $(2)$ & $8.7(3.8)$ & $6.8(7.3)$ & $<10$ \\
Biv (3) & $2.6(0.6)$ & $7.2(3.4)$ & $79.3(2.7)$ \\
SD $_{\mathrm{p}}(4)$ & $5.6(3.9)$ & $5.8(0.1)$ & $<10$ \\
$\mathrm{SW}_{\mathrm{p}}(5)$ & $6.8(3.4)$ & $10.0(5.1)$ & $<10$ \\
$\mathrm{SW}_{\mathrm{h}}(6)$ & $4.3(0.6)$ & $12.8(6.5)$ & $28.5(17)$ \\
\hline
\end{tabular}

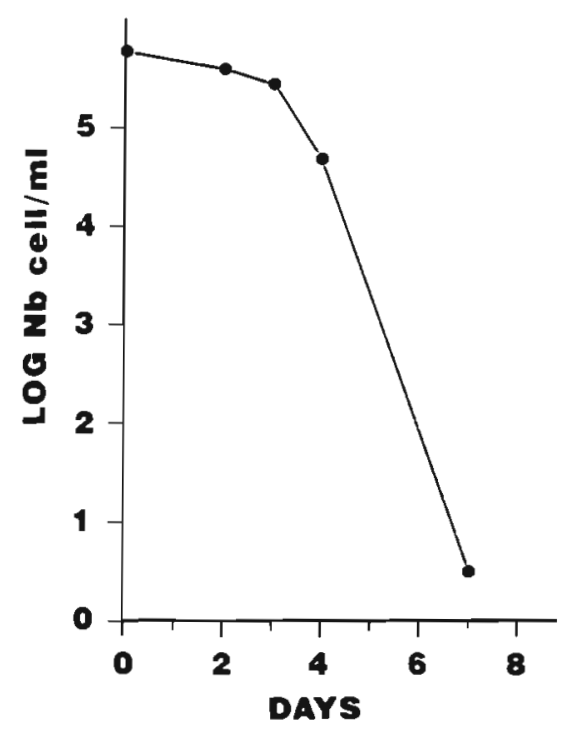

Fig. 2. Vibrio sp. Survival of VTP in seawater

longer detected by immunofluorescence in $100 \mathrm{ml}$ of seawater filtered through a $0.2 \mu \mathrm{m}$ membrane. Nevertheless, VTP was still present after $10 \mathrm{~d}$, since $500 \mathrm{ml}$ of this contaminated seawater, poured into a $2 \mathrm{l}$ beaker containing healthy larvae, induced mortality

The number of viable cells sufficient to initiate the disease in larvae was $<1$ cell $5 \mathrm{ml}^{-1}$ (Table 5). Moreover, the delay in mortality between the highest and lowest concentration did not exceed $2 \mathrm{~d}$.

Direct counts by immunofluorescence indicated an equivalent number of VTP in larvae and the surrounding seawater during the mortality period (seawater: 1.5 $\times 10^{4}$ to $3 \times 10^{6}$ cells $\mathrm{ml}^{-1}$; larvae: $1.5 \times 10^{3}$ to $7 \times 10^{5}$ cells larva ${ }^{-1}$ ). 
Table 5. Tapes philippinarum infected by Vibrio sp. Determination of the cell number of the pathogenic strain sufficient to induce disease in $3 \mathrm{~d}$ old larvae; values are mortality in percent (SD in parentheses)

\begin{tabular}{|c|c|c|c|c|}
\hline \multirow[t]{2}{*}{ Batches } & \multicolumn{4}{|c|}{ Days after inoculation } \\
\hline & 3 & 4 & 5 & 6 \\
\hline Control & $4.8(2.8)$ & & $11.3(8.1)$ & $17.3(8.3)$ \\
\hline $4 \times 10^{4}$ cells $\mathrm{ml}^{-1}$ a & $39.0(1.5)$ & $85.7(1.3)$ & 100 & \\
\hline 20 cells $\mathrm{ml}^{-1}$ & $11.3(2.1)$ & & $87.1 \quad(1.4)$ & $98.0(0.3)$ \\
\hline 2 cells $\mathrm{ml}^{-1}$ & $12.8(0.3)$ & & $61.3\{6.1\}$ & $98.0 \quad(0.3)$ \\
\hline 1 cell $5 \mathrm{ml}^{-1}$ & $11.0(1.3)$ & & $40.8(4.8)$ & $92.5(1.7)$ \\
\hline
\end{tabular}

\section{Specificity of VTP}

Oyster and scallop larvae were not sensitive to VTP No mortality was observed after $1 \mathrm{wk}$. The number of VTP, followed by direct counts and plate counts, showed a rapid decrease and disappearance in oyster larvae and seawater (Table 6).

\section{Sensitivity to lysozyme}

VTP was resistant to the different lysozymes, whereas Escherichia coli, Vibrio anguillarum and Micrococcus lysodekticus were sensitive to lysozyme activity (Table 7).

\section{DISCUSSION AND CONCLUSION}

The causal agent of this disease was isolated and identified as a Vibrio sp. with an affinity to Vibrio marinus. It was not related to the vibrio of brown ring disease, since their characters on API 20E were very different and no cross-reaction occurred with the respective antisera (Paillard \& Maes 1990).

VTP did not kill scallop and oyster larvae. This is the first report of a highly specific bacterial strain pathogenic to bivalve larvae, but additional tests with Tapes decussatus larvae would further elicit its specificity. Vibrio anguillarum and $V$. tubiashii are considered pathogens for several species (Brown 1981, Jeffries 1982, Garland et al. 1983, Lodeiros et al. 1987).

Table 6. Crassostrea gigas exposed to Vibrio sp. Sensitivity of oyster larvae to VTP and elimination of VTP. Direct counts were made using immunofluorescence in one contaminated beaker

\begin{tabular}{|ccccc|}
\hline $\begin{array}{c}\text { Days after } \\
\text { inoculation }\end{array}$ & \multicolumn{2}{c|}{$\begin{array}{c}\text { Mortality (\%) } \\
\text { Control }\end{array}$} & Contaminated & \multicolumn{2}{c|}{ Direct counts of VTP } \\
Per $100 \mathrm{ml}$ seawater \\
\hline 2
\end{tabular}

Table 7. Lysozyme activity on VTP in comparison with a reference strain (Micrococcus lysodeikticus) and 2 gram-negative strains (Escherichia coli and Vibrio anguillarum). Values represent the average change in optical density $\mathrm{s}^{-1}$ over a period of $10 \mathrm{~min}$. nd: not determined

\begin{tabular}{|lllc|}
\hline Strains & Oyster larvae & $\begin{array}{c}\text { Lysozyme from: } \\
\text { Scallop larvae }\end{array}$ & Chicken egg white \\
\hline M. lysodeikticus & $7.9 \times 10^{-5}$ & $2.0 \times 10^{-4}$ & $1.3 \times 10^{-3}$ \\
VTP & 0 & 0 & 0 \\
E. coli & nd & $3.0 \times 10^{-5}$ & $4.1 \times 10^{-4}$ \\
V. anguillarum & nd & $6.6 \times 10^{-5}$ & $7.8 \times 10^{-4}$ \\
\hline
\end{tabular}


Other pathogenic vibrios have been tested only on Crassostrea virginica larvae (Brown \& Losee 1978, Elston \& Leibovitz 1980) or on Ostrea edulis larvae and spat (Nottage \& Birkbeck 1986, 1987) and their degree of specificity remains unknown. However, VTP seemed to be particularly specific, and it possessed unusual traits: it did not grow on TCBS agar; it did not survive very long in seawater, or quickly became undetectable; it was resistant to chloramphenicol; a small number of cells could provoke the disease; it was resistant to lysozyme activity; and it was pathogenic for postlarvae.

The survival time for VTP in the seawater was closer to that of a freshwater bacterium, such as Aeromonas salmonicida (Rose et al. 1990), than that of a marine bacterium. For example, the Vibrio of brown ring disease survived $7 \mathrm{~d}$ without decreased viability (Maes pers. comm.). Nevertheless, it is considered a true marine bacterium since it requires sodium chloride for yrowih.

The spontaneous disappearance of VTP in seawater makes it difficult to detect. This may explain why, in the second experiment (see Table 2), VTP was not isolated in the batch inoculated with sick larvae. Indeed, as mortality occurred sooner than in the other contaminated batches, it may have been at a low level on the sampling day and saprophytic bacteria, especially vibrios, may have been masking it.

Since VTP seemed to multiply only in larvae, the mechanism of infection may be invasive. Attempts to detect toxins of VTP using the methods of Nottage \& Birkbeck (1986) have failed (Birkbeck pers. comm.). Its resistance to lysozyme activity may permit an initial multiplication in the digestive tract. The tissues may then be progressively attacked. The high number of bacteria observed by TEM in the digestive tract prior to the formation of lesions corroborated this hypothesis. This pathogenesis is very similar to pathogenesis type III described by Elston \& Leibovitz (1980).

Oyster and scallop larvae were resistant to VTP, although their lysozyme could not inactivate it. Other digestive enzymes which could lyse bacteria in bivalves have not been reported in the literature. Lysozyme is apparently the only digestive enzyme which can digest the peptidoglycan of bacteria in bivalves (Birkbeck \& McHenery 1982). Thus a specific attachment to the digestive wall of Manila clam would explain the specificity of VTP and the resistance to it by oyster and scallop larvae. This has already been suggested by Elston \& Leibovitz (1980) in regard to pathogenesis type III. According to the review of Finlay $\&$ Falkow (1989) adhesion plays a significant role in the colonization of different sites, especially the digestive tract of mammals. This could also explain why even a small number of bacteria could induce the disease.

Two types of adhesion are known: frimbrial and non-fimbrial. Pili in the Vibrionacae were originally observed by Tweeby et al. (1968), but recently, investigations in this area have been carried out in the field of aquaculture. Some observations have shown that vibrios can attach to the host target. A vibrio pathogenic to the flounder Paralichthys olivaceus was found to bind to a cell line (Muroga et al. 1990). Elston \& Leibovitz (1980) also observed an invasive Vibrio sp. attached to the periostracum and shell of oyster Iarvae. A very specific attachment due to pili occurred on the periostracal lamina in association with brown ring disease (Paillard 1992); this has only been observed on this part of the periostracum and in Manila clam. Certainly attachment may play an important role for invasive bacteria in marine animals and needs further investigation.

The epidemiological study revealed the contaminated areas in and around the hatchery. VTP was primarily found in bivalve tissues and in the pond. Howcver, it was also present in the inlet seawater in the first and second experiments. Seawater was pumped from the open sea through beach sand, where no VTP was detected; therefore, VTP could only have multiplied in the sand filter where it could colonize some small animals, since the seawater pipes are frequently chlorinated. Sediments did not seem to be contaminated by VTP. VTP did not multiply or survive in algal culture, but vibrios do not generally occur in healthy algal culture (Prieur 1981. Nicolas et al. 1989).

Finally, VTP was eliminated in the hatchery and its surrounding environment by drying out the pond and by drying out and disinfecting the facilities for $11 / 2 \mathrm{mo}$. Since 1987, this pathogen has not been observed.

\section{LITERATURE CITED}

Baumann, P., Furniss, A. L., Lee, J. V (1984). Genus 1. Vibrio Pacini 1854, $411^{\mathrm{AL}}$. In: Krieg, N. R. (ed.) Bergey's manual of systematic bacteriology, Vol. 1 . Williams \& Wilkins, Baltimore, p. 518-538

Birkbeck, T H., McHenery, J. G. (1982). Degradation of Bacteria by Mytilus edulis. Mar. Biol. 72: 7-15

Brown, C. (1973). The effect of some selected bacteria on embryos and larvae of the American oyster, Crassostrea virginica. J. Invertebr Pathol, 21. 215-223

Brown, C. (1981). A study of two shellfish-pathogenic Vibrio strains isolated from a Long Island hatchery during a recent outbreak of disease. J. Invertebr. Pathol. 38: 281-293

Brown, C. Losee, E. (1978). Observations on natural and induced epizootics of vibriosis in Crassostrea virginica larvae. J. Invertebr. Pathol. 31. 41-47

DiSalvo, L. H., Blecka, J., Zebal, R. (1978). Vibrio anguillarum and larval mortality in California coastal shellfish hatchery. Appl environ. Microbiol. 35: 219-221

Elston, R., Leibovitz, L. (1980). Pathogenesis of experimental vibriosis in larval American Oysters, Crassostrea virginica. Can. J. Fish. Aquat. Sci. 37: 964-978

Finlay, B. B., Falkow, S. (1989). Common themes in microbial pathogenicity. Microbiol. Rev. 53(2): 210-230 
Garland, C. D., Nash, G. V., Summer, C. E., McMeekin, T A. (1983). Bacterial pathogens of oyster larvae (Crassostrea gigas) in a Tasmanian hatchery. Aust. J. mar Freshwat. Res. 34: 483-487

Gruffydd, L. D., Beaumont, A. R. (1972). A method for rearing Pecten maximus larvae in the laboratory. Mar. Biol. 15: 350-355

Jeffries, V. E. (1982). Three Vibrio strains pathogenic to larvae of Crassostrea gigas and Ostrea edulis. Aquaculture 29: 201-226

Kent, M. L. (1982). Characteristics and identification of Pasteurella and Vibrio species pathogenic to fishes using API20E (Analytab Products) multitube test strips. Can. J. Fish. Aquat. Sci. 39: 1725-1729

Lodeiros, C., Bolinches, J., Dopazo, C. P., Toranzo, A. E. (1987). Bacillary necrosis in hatcheries of Ostrea edulis in Spain. Aquaculture 65: 15-29

MacDonell, M. T., Singleton, F. L., Hood, M. A. (1982). Diluent composition for use of API 20E in characterizing marine and estuarine bacteria. Appl. environ. Microbiol. 44: 423-427

McHenery, J. G., Birkbeck, T. H. (1982). Characterization of the lysozyme of Mytilus edulis (L). Comp. Biochem. Physiol. 4: $583-589$

Muroga, K., Yasunobu, H., Okada, N., Masumura, K. (1990). Bacterial enteritis of cultured flounder Paralichthys olivaceus larvae. Dis. aquat. Org. 9: 121-125

Nicolas, J. L., Robic, E., Ansquer, D. (1989). Bacterial flora associated with a trophic chain consisting of microalgae, rotifers and turbot larvae: influence of bacteria on larval survival. Aquaculture 83: 237-248

This article was presented by A. K. Sparks, Seattle, Washington, USA
Nottage, A. S., Birkbeck, T. H. (1986). Toxicity to marine bivalves of culture supernatant fluids of the bivalvepathogenic Vibrio strain NCMB 1338 and other marine vibrios. J. Fish Dis. 10: 265-273

Nottage, A. S., Birkbeck, T H. (1987). Production of proteinase during experimental infection of Ostrea edulis L. larvae with Vibrio alginoliticus NCMB 1339 and the antigenic relationship between proteinase produced by marine vibrios pathogenic for fish and shellfish. J. Fish Dis. 10: $265-273$

Paillard, C. (1992). Etiologie et caractérisation de la maladie de l'anneau brun chez la palourde d'élevage Ruditapes philippinarum. Thèse d'Université, UBO, Brest, France

Paillard, C., Maes, P. (1990). Etiologie de la maladie de l'anneau brun chez Tapes philippinarum: pathogénicité d'un Vibrio sp. C. r. Acad. Sci., Paris 310: 15-20

Prieur, D. (1981). Les relations entre mollusques bivalves et bactéries hétérotrophes en milieu marin. Etude analytique et expérimentale. Thèse Doctorat d'Etat de Sciences Naturelles, Brest, France

Rose, A. S., Ellis, A. E., Munro, A. L. S. (1990). The survival of Aeromonas salmonicida subsp. salmonicida in seawater. J. Fish Dis. 13: 205-214

Tweeby, J. M., Park, R. W. A., Hodgkiss, W (1968). Evidence for the presence of fimbriae (pili) on Vibrio species. J. gen. Microbiol. 51: 235-244

West, P. A., Colwell, R. R. (1984). Identification and classification of Vibrionacae. An overview. In: Colwell, R. R. (ed.) Vibrios in the environment. John Wiley and Sons, New York, p. 285-363

Manuscript first received: April 12, 1991

Revised version accepted: July 24, 1992 